Sains Malaysiana 49(11)(2020): 2859-2870

http://dx.doi.org/10.17576/jsm-2020-4911-24

\title{
Explicit Schemes based on Rational Approximant for Solving First Order Initial Value Problems
}

(Skim tak Tersirat berdasarkan Pendekatan Nisbah bagi Menyelesaikan Masalah Nilai Awal Peringkat Pertama)

\author{
A’IN NAZIFA FAIRUZ, ZANARIAH ABDUl MAJID* \& ZARINA BIBI IBRAHIM
}

\begin{abstract}
A class of rational methods of the second, third and fourth-order are proposed in this study. The formulas are developed based on a rational function with the denominator of degree one. Besides that, the concept of the closest points of approximation is also emphasized in formulating these methods. The derived methods are not self-starting; thus, an existing rational method is applied to calculate the starting values. The stability regions of the methods are also illustrated in this paper and suggest that only the second-order method is A-stable, while the third and fourth-order methods are not. The proposed formulas are examined on different problems, in which the solution possesses singularity, stiff and singularly perturbed problems. The numerical results show the capability of the proposed methods in solving problems with singularity. It also suggests that the developed schemes are more accurate than the existing rational multistep methods for problems with integer singular point. It is also shown that the derived schemes are suitable for solving stiff and singularly perturbed problems, although some of the formulas are not A-stable.
\end{abstract}

Keywords: Problem which solution possesses singularity; rational methods; singularly perturbed problem; stiff problem

ABSTRAK

Suatu kelas kaedah nisbah bagi peringkat kedua, ketiga dan keempat dicadangkan dalam kajian ini. Kaedah ini dirumus berdasarkan fungsi nisbah yang mempunyai penyebut berdarjah satu. Selain itu, konsep titik penghampiran terdekat juga ditekankan dalam merumus kaedah ini. Kaedah yang dirumus ini merupakan kaedah yang tidak bermula dengan sendirinya. Justeru, suatu kaedah nisbah sedia ada digunakan untuk menghitung nilai pemula. Rantau kestabilan bagi kaedah nisbah tersebut juga dijelaskan dan mencadangkan bahawa hanya kaedah peringkat kedua adalah A-stabil, manakala kaedah peringkat ketiga dan keempat pula bukan A-stabil. Kaedah yang dicadangkan telah diuji pada masalah yang berbeza, iaitu masalah dengan penyelesaian yang mempunyai kesingularan, kekakuan dan pengusikan singular. Hasil berangka menunjukkan kebolehan kaedah tersebut dalam menyelesaikan masalah dengan kesingularan. Hasil juga mencadangkan bahawa penghampiran yang diberikan oleh kaedah yang dirumus adalah lebih jitu berbanding kaedah multilangkah nisbah bagi masalah dengan titik singular integer. Keputusan juga menunjukkan bahawa kaedah yang dicadangkan sesuai untuk menyelesaikan masalah kekakuan dan masalah dengan pengusikan singular walaupun sebahagian daripada rumus tersebut bukanlah A-stabil.

Kata kunci: Kaedah nisbah; masalah dengan pengusikan singular; masalah dengan penyelesaian yang mempunyai kesingularan; masalah kekakuan

\section{INTRODUCTION}

Mathematical structures describing complex systems involve multiple elements that interact between one another in various forms is the end product of realworld data analysed and formalized. These interactions exist in physics, electromagnetic, mechanics, biology, signal processing, finance, and economics. In order to make sense of the data extracted from such elements, the evolution of the data against time is utilized. The immediate observation would be a system of differential equations. Upon solving such differential equations, the obtained function will have information that can be used to extract and understand the data at hand and further predict the future information related to the data. Among special classes of differential equations are problems which solution possesses singularity, stiff, and singularly 
perturbed problems. Fundamental investigation on these classes of differential equations is pertinent in order to interpret data which evolves into such form.

Rational methods have been introduced as an approach for solving initial value problems (IVP) of the form;

$y^{\prime}(x)=f(x, y(x)), y(a)=\eta ; y(x), f(x, y(x)) \in R, x \in[a, b] \subset R(1)$

which exhibit unique characteristics as considered by some authors, such as possessing singularity in its solution or being stiff. The conventional methods developed based on polynomial functions, such as Linear Multistep Methods and Runge-Kutta Methods, face difficulties in approximating such problems, especially in the neighbourhood of singularity. On the other hand, Ikhile (2001) stated that numerical schemes developed based on rational functions are more reliable in solving these problems due to its smooth behaviour around this range of points.

Problems which solution possesses singularity are problems that fail to satisfy the requirement of existence and uniqueness theorem near to the singular points, which leads to the poor performance of the conventional methods in these range of points, as stated by Ikhile (2001). Meanwhile, stiff problems can be recognized as problems in which some components of the solution decays rapidly than others. In addition, Ramos et al. (2015) stated that singularly perturbed problems could be identified by the presence of a small parameter (usually $\epsilon$ ) that multiplies the first-order derivative, which causes it to have stiffness characteristics.

Numerical approaches derived from rational approximants, or better known as rational methods, to solve problems with singularity have been studied by several authors (Abelman \& Eyre 1990; Fatunla 1986; Nierkek 1988). From the studies, a different form of rational functions has been proposed. Moreover, Gadella and Lara (2013) as well as Adeboye and Umar (2013) adapted Pade' approximant in developing rational schemes to approximate rigid equation and oscillatory problem, respectively, besides solving the problem with singularity. Some researchers also considered developing rational methods for solving problems with stiffness properties (Ramos et al. 2017, 2015; Teh at al. 2011). Other than the conventional rational methods, some ideas in improving the formulas have been introduced by Teh (2014) and Teh et al. (2016). Teh (2014) proposed a second-order rational scheme without the requirement of higher derivative, while Teh et al. (2016) introduced the idea of block methods based on a rational function which possessed a third-order accuracy.

Additionally, the studies on rational approaches include one-step and multistep schemes. For example,
Otunta and Nwachukwu (2005) proposed a one-step rational method of order six. Meanwhile, for multistep methods, such formulas can be seen in the works done by Okosun and Ademiluyi (2007a, 2007b) and Teh and Yaacob (2013), where the authors developed rational methods with the distance between the approximation points of 2 or $3 \mathrm{~h}$. From the literature, it is preferable to establish a class of rational methods suitable in solving problems with singularity and stiffness properties, besides considering to reduce the distance of points of approximation in the formula.

In this paper, we present a class of rational methods of order $p$, or $R M(1, p)$, derived based on a rational function with the denominator of degree one proposed in this study. Besides that, the idea of the closest points of approximation is also considered, and the distance between the points is reduced to $h$. The formulation, stability and implementation of the methods are discussed in this paper. The proposed rational schemes are tested on problems with singularity in its solution, stiff and singularly perturbed problems, where the numerical results are compared to the results generated by several existing methods.

\section{MATERIALS AND METHOdS RM $(1,2)$}

DEVELOPMENT OF RATIONAL METHODS $(\operatorname{RM}(1, p))$

We propose an approximation for $y\left(x_{n+3}\right)$, denoted by $y_{n+3}$, generally written as follows:

$$
y_{n+3}=\alpha+\frac{\sum_{i=1}^{K} a_{i} h^{i}}{b_{0}+\sum_{j=1}^{M} h^{j}},
$$

where from (2), various combination of $K$ and $M$ values in the numerator and denominator, respectively, can be considered. Nevertheless, it is desirable to obtain the simplest form of the rational function in (2) as well as the resulting rational formulas. Therefore, we consider to set the denominator to be of degree $M=1$, as the value of varies for $K=1,2,3$. By substituting $M=1$ into (2), the rational function can be expressed as (3):

$$
y_{n+3}=\alpha+\frac{\sum_{i=1}^{K} a_{i} h^{i}}{b_{0}+h}, \text { where } b_{0}+h \neq 0
$$

where $\alpha, b_{0}$ and $a_{i}, i=1,2, \ldots, K$ are parameters that may contain approximations of $y\left(x_{n+2}\right)$ and higher derivatives of $y\left(x_{n+2}\right)$.

Based on the formula in (3), the linear difference operator associated to the function is given as;

$$
\begin{aligned}
L[y(x) ; h]_{R M(1, p)} & =\left(y\left(x_{n+3}\right)-\alpha\right)\left(b_{0}+h\right)-\sum_{i=1}^{K} a_{i} h^{i} \\
& =\left(y\left(x_{n+2}+h\right)-\alpha\right)\left(b_{0}+h\right)-\sum_{i=1}^{K} a_{i} h^{i},
\end{aligned}
$$


where $y\left(x_{n+2}+h\right)$ represents $y\left(x_{n+3}\right)$ in order to lessen the gap between the points of approximation in the formula. On the other hand, $y(x)$ is arbitrary and continuously differentiable on $x \in[a, b]$. Next, the term $y\left(x_{n+2}+\mathrm{h}\right)$ is expanded as Taylor series around $x_{n+2}$ and upon collecting terms in the difference operator in (4), we obtain the following expression;

$$
\begin{gathered}
L[y(x) ; h]_{R M(1, p)}=C_{0} h^{0}+C_{1} h^{1}+\cdots+C_{K} h^{K} \\
+C_{K+1} C^{K+1}+\cdots
\end{gathered}
$$

Note that $C_{i}, j=0,1, \ldots, K, K+1$ in expression (5) contain the parameters to be determined throughout the derivation process. The order and parameters can be obtained according to the definition herewith.

Definition 1. The difference operator in equation (4) and the associated rational method (3) are said to be of order $p=K+1$ if, in expression (4), $C_{0}=C_{1}=\ldots=C_{K}=C_{(K+1)}$ $=0, C_{(K+2)} \neq 0$.

\section{SECOND ORDER RATIONAL METHODS $R M(1,2)$}

In order to derive a second order method, $R M(1,2)$, we consider $K=1$ in (3). Thus, the rational function associated to the method is given by;

$$
y_{n+3}=\alpha+\frac{a_{1} h}{b_{0}+h}
$$

and the associated linear difference operator is given as;

$$
L[y(x) ; h]_{R M(1,2)}=\left(y\left(x_{n+2}+h\right)-\alpha\right)\left(b_{0}+h\right)-a_{1} h .
$$

Next, we expand $y\left(x_{n+2}+h\right)$ as Taylor series around $x_{n+2}$ and obtain the expression;

$L[y(x) ; h]_{R M(1,2)}$

$$
\begin{aligned}
& =-\alpha b_{0}+b_{0} y\left(x_{n+2}\right) \\
& +h\left(-a_{1}-\alpha+y\left(x_{n+2}\right)+b_{0} y^{\prime}\left(x_{n+2}\right)\right) \\
& +h^{2}\left(y^{\prime}\left(x_{n+2}\right)+\frac{1}{2} b_{0} y^{\prime \prime}\left(x_{n+2}\right)\right) \\
& +h^{3}\left(\frac{1}{2} y^{\prime \prime}\left(x_{n+2}\right)+\frac{1}{6} b_{0} y^{\prime \prime \prime}\left(x_{n+2}\right)\right)+O\left(h^{4}\right) .
\end{aligned}
$$

From expression (8), it can be deduced that;

$$
\begin{aligned}
& C_{0}=-\alpha b_{0}+b_{0} y\left(x_{n+2}\right), \\
& C_{1}=-a_{1}-\alpha+y\left(x_{n+2}\right)+b_{0} y^{\prime}\left(x_{n+2}\right), \\
& C_{2}=y^{\prime}\left(x_{n+2}\right)+\frac{1}{2} b_{0} y^{\prime \prime}\left(x_{n+2}\right), \\
& C_{3}=\frac{1}{2} y^{\prime \prime}\left(x_{n+2}\right)+\frac{1}{6} b_{0} y^{\prime \prime \prime}\left(x_{n+2}\right) .
\end{aligned}
$$

Since $K=1$, and according to Definition $1, C_{0}=C_{1}=C_{2}=0$, thus by solving $C_{j}$ in (9) simultaneously and taking $y_{n+2}$ as the approximation of theoretical solution $y\left(x_{n+2}\right)$, we obtain the parameters $\alpha, b_{0}$ and $a_{1}$ in rational function (5) as;

$$
\begin{aligned}
& \alpha=y_{n+2}, \\
& a_{1}=-\frac{2\left(y_{n+2}^{\prime}\right)^{2}}{y_{n+2}^{\prime \prime}}, \\
& b_{0}=-\frac{2 y_{n+2}^{\prime}}{y_{n+2}^{\prime \prime}},
\end{aligned}
$$

where by localizing assumption, $y_{n+2}=y\left(x_{n+2}\right), y_{n+2}^{\prime}=y^{\prime}\left(x_{n+2}\right)$ and $y^{\prime \prime}{ }_{n+2}=y^{\prime \prime}\left(\mathrm{x}_{n+2}\right)$. Substituting (10) into $C_{3}$, we obtain;

$$
C_{3}=-\frac{y_{n+2}^{\prime} y_{n+2}^{\prime \prime \prime}}{3 y_{n+2}^{\prime \prime}}+\frac{y_{n+2}^{\prime \prime}}{2} \text {. }
$$

Based on (6) and (10), $R M(1,2)$ can be written as;

$$
y_{n+3}=y_{n+2}+\frac{2 h\left(y_{n+2}^{\prime}\right)^{2}}{2 y_{n+2}^{\prime}-h y_{n+2}^{\prime \prime}} .
$$

\section{THIRD ORDER RATIONAL METHODS RM(1,3)}

To derive the third order method, $K=2$ is substituted into (3), hence the rational function for the method is given by;

$$
y_{n+3}=\alpha+\frac{a_{1} h+a_{2} h^{2}}{b_{0}+h},
$$

and the associated linear difference operator is;

$L[y(x) ; h]_{R M(1,3)}=\left(y\left(x_{n+2}+h\right)-\alpha\right)\left(b_{0}+h\right)-a_{1} h-a_{2} h^{2}$.

Expanding $y\left(x_{n+2}+h\right)$ as Taylor series, we obtain; $L[y(x) ; h]_{R M(1,3)}$

$$
\begin{aligned}
& =-\alpha b_{0}+b_{0} y\left(x_{n+2}\right)+h\left(-a_{1}-\alpha+y\left(x_{n+2}\right)+b_{0} y^{\prime}\left(x_{n+2}\right)\right) \\
& +h^{2}\left(-a_{2}+y^{\prime}\left(x_{n+2}\right)+\frac{1}{2} b_{0} y^{\prime \prime}\left(x_{n+2}\right)\right) \\
& +h^{3}\left(\frac{1}{2} y^{\prime \prime}\left(x_{n+2}\right)+\frac{1}{6} b_{0} y^{\prime \prime \prime}\left(x_{n+2}\right)\right) \\
& +h^{4}\left(\frac{1}{6} y^{\prime \prime \prime}\left(x_{n+2}\right)+\frac{1}{24} b_{0} y^{(4)}\left(x_{n+2}\right)\right)+O\left(h^{5}\right) .
\end{aligned}
$$

From (15), the following equations are deduced;

$$
\begin{aligned}
& C_{0}=-\alpha b_{0}+b_{0} y\left(x_{n+2}\right), \\
& C_{1}=-a_{1}-\alpha+y\left(x_{n+2}\right)+b_{0} y^{\prime}\left(x_{n+2}\right), \\
& C_{2}=-a_{2}+y^{\prime}\left(x_{n+2}\right)+\frac{1}{2} b_{0} y^{\prime \prime}\left(x_{n+2}\right), \\
& C_{3}=\frac{1}{2} y^{\prime \prime}\left(x_{n+2}\right)+\frac{1}{6} b_{0} y^{\prime \prime \prime}\left(x_{n+2}\right), \\
& C_{4}=\frac{1}{6} y^{\prime \prime \prime}\left(x_{n+2}\right)+\frac{1}{24} b_{0} y^{(4)}\left(x_{n+2}\right) .
\end{aligned}
$$


Note that $K=2$, and according to Definition $1, C_{0}=C_{1}=$ $C_{2}=C_{3}=0$. Next, $C_{j}$ in (16) are solved simultaneously, and by taking $y_{n+2}$ as the approximation of the theoretical solution $y\left(x_{n+2}\right)$, we obtain the unknown parameters in rational function (13) as;

$$
\begin{aligned}
\alpha & =y_{n+2}, \\
a_{1} & =-\frac{3 y_{n+2}^{\prime} y_{n+2}^{\prime \prime}}{y_{n+2}^{\prime \prime}}, \\
a_{2} & =\frac{-3\left(y_{n+2}^{\prime \prime}\right)^{2}+2 y_{n+2}^{\prime} y_{n+2}^{\prime \prime \prime}}{2 y_{n+2}^{\prime \prime \prime}}, \\
b_{0} & =-\frac{3 y_{n+2}^{\prime \prime}}{y_{n+2}^{\prime \prime \prime}},
\end{aligned}
$$

where by localizing assumption, $y_{n+2}=y\left(x_{n+2}\right), y_{n+2}^{\prime}=y^{\prime}\left(x_{n+2}\right)$, $y^{\prime \prime}{ }_{n+2}=y^{\prime \prime}\left(x_{n+2}\right)$ and $y^{\prime \prime \prime}{ }_{n+2}=y^{\prime \prime \prime}\left(x_{n+2}\right)$. From (17), we obtain $C_{4}$ as follows;

$$
C_{4}=-\frac{y_{n+2}^{\prime \prime} y_{n+2}^{(4)}}{8 y_{n+2}^{\prime \prime \prime}}+\frac{y_{n+2}^{\prime \prime \prime}}{6} .
$$

By substituting (17) into (13), we obtain $R M(1,3)$ as follows;

$$
y_{n+3}=y_{n+2}+\frac{6 h y_{n+2}^{\prime} y_{n+2}^{\prime \prime}+h^{2}\left[3\left(y_{n+2}^{\prime \prime}\right)^{2}-2 y_{n+2}^{\prime} y_{n+2}^{\prime \prime \prime}\right]}{6 y_{n+2}^{\prime \prime}-2 h y_{n+2}^{\prime \prime \prime}} \text {. }
$$

FOURTH ORDER RATIONAL METHODS RM(1,4)

To derive the fourth order method, $R M(1,4), K=3$ is substituted into (3), which yields the rational function for the method given by;

$$
y_{n+3}=\alpha+\frac{a_{1} h+a_{2} h^{2}+a_{3} h^{3}}{b_{0}+h}
$$

and the associated linear difference operator given by;

$$
\begin{aligned}
L[y(x) ; h]_{R M(1,4)} & =\left(y\left(x_{n+2}+h\right)-\alpha\right)\left(b_{0}+h\right)-a_{1} h \\
& -a_{2} h^{2}-a_{3} h^{3} .
\end{aligned}
$$

Expanding $y\left(x_{n+2}+h\right)$ as Taylor series, we obtain; $L[y(x) ; h]_{R M(1,4)}$

$$
\begin{aligned}
& =-\alpha b_{0}+b_{0} y\left(x_{n+2}\right)+h\left(-a_{1}-\alpha+y\left(x_{n+2}\right)+b_{0} y^{\prime}\left(x_{n+2}\right)\right) \\
& +h^{2}\left(-a_{2}+y^{\prime}\left(x_{n+2}\right)+\frac{1}{2} b_{0} y^{\prime \prime}\left(x_{n+2}\right)\right) \\
& +h^{3}\left(-a_{3}+\frac{1}{2} y^{\prime \prime}\left(x_{n+2}\right)+\frac{1}{6} b_{0} y^{\prime \prime \prime}\left(x_{n+2}\right)\right) \\
& +h^{4}\left(\frac{1}{6} y^{\prime \prime \prime}\left(x_{n+2}\right)+\frac{1}{24} b_{0} y^{(4)}\left(x_{n+2}\right)\right) \\
& +h^{5}\left(\frac{1}{24} y^{(4)}\left(x_{n+2}\right)+\frac{1}{120} b_{0} y^{(5)}\left(x_{n+2}\right)\right)+O\left(h^{6}\right) .
\end{aligned}
$$

From expression (22), we obtain;

$$
\begin{aligned}
& C_{0}=-\alpha b_{0}+b_{0} y\left(x_{n+2}\right), \\
& C_{1}=-a_{1}-\alpha+y\left(x_{n+2}\right)+b_{0} y^{\prime}\left(x_{n+2}\right), \\
& C_{2}=-a_{2}+y^{\prime}\left(x_{n+2}\right)+\frac{1}{2} b_{0} y^{\prime \prime}\left(x_{n+2}\right), \\
& C_{3}=-a_{2}+y^{\prime}\left(x_{n+2}\right)+\frac{1}{2} b_{0} y^{\prime \prime}\left(x_{n+2}\right), \\
& C_{4}=\frac{1}{6} y^{\prime \prime \prime}\left(x_{n+2}\right)+\frac{1}{24} b_{0} y^{(4)}\left(x_{n+2}\right), \\
& C_{5}=\frac{1}{24} y^{(4)}\left(x_{n+2}\right)+\frac{1}{120} b_{0} y^{(5)}\left(x_{n+2}\right) .
\end{aligned}
$$

From Definition 1, it is known that $C_{0}=C_{1}=C_{2}=C_{3}=$ $C_{4}=0$. Thus, by solving $C_{j}$ in (23) simultaneously and taking $y_{n+2}$ as the approximation of the theoretical solution $y\left(x_{n+2}\right)$,

$$
\begin{aligned}
& \alpha=y_{n+2}, \\
& a_{1}=-\frac{4 y_{n+2}^{\prime} y_{n+2}^{\prime \prime \prime}}{y_{n+2}^{(4)}}, \\
& a_{2}=\frac{-2 y_{n+2}^{\prime \prime} y_{n+2}^{\prime \prime \prime}+y_{n+2}^{\prime} y_{n+2}^{(4)}}{y_{n+2}^{(4)}}, \\
& a_{3}=\frac{-4\left(y_{n+2}^{\prime \prime \prime}\right)^{2}+3 y_{n+2}^{\prime \prime} y_{n+2}^{(4)}}{6 y_{n+2}^{(4)}}, \\
& b_{0}=-\frac{4 y_{n+2}^{\prime \prime \prime}}{y_{n+2}^{(4)}}
\end{aligned}
$$

we obtain the unknown parameters in rational function (20) as;

where by localizing assumption, $y_{n+2}=y\left(x_{n+2}\right), y_{n+2}^{\prime}=y^{\prime}$ $\left(x_{n+2}\right), y_{n+2}^{\prime \prime}=y^{\prime \prime}\left(x_{n+2}\right), y^{\prime \prime \prime}{ }_{n+2}=y^{\prime \prime \prime}\left(x_{n+2}\right)$ and $y_{n+2}^{(4)}=y^{(4)}\left(x_{n+2}\right)$. Upon substituting equations in (24) into $C_{5}$ we have;

$$
C_{5}=-\frac{y_{n+2}^{\prime \prime \prime} y_{n+2}^{(5)}}{30 y_{n+2}^{(4)}}+\frac{y_{n+2}^{(4)}}{24} \text {. }
$$

By substituting (24) into (20), we obtain $\operatorname{RM}(1,4)$ as follows;

$$
y_{n+3}=y_{n+2}+\frac{\left[\begin{array}{c}
h\left(24 y_{n+2}^{\prime} y_{n+2}^{\prime \prime \prime}\right)+h^{2}\left(12 y_{n+2}^{\prime \prime} y_{n+2}^{\prime \prime \prime}-6 y_{n+2}^{\prime} y_{n+2}^{(4)}\right) \\
+h^{3}\left(4\left(y_{n+2}^{\prime \prime \prime}\right)^{2}-3 y_{n+2}^{\prime \prime} y_{n+2}^{(4)}\right)
\end{array}\right]}{24 y_{n+2}^{\prime \prime \prime}-6 h y_{n+2}^{(4)}} .
$$




\section{LOCAL TRUNCATION ERROR OF RM( $1, p)$}

The Local Truncation Errors (LTE) of $\operatorname{RM}(1, p), p=2,3,4$, are determined according to the following definition.

Definition 2. The local truncation error at $x_{n+3}$ of equation (3) is defined to be the expression $L\left[y\left(x_{n+2}\right) ; h\right]_{R M(1, p)}$ given by equation (4), when $y\left(x_{n+2}\right)$ is the theoretical solution of the initial value problem at point $x_{n+2}$. The local truncation error of equation (3) is then;

$$
L\left[y\left(x_{n+2}\right) ; h\right]_{R M(1, p)}=C_{K+2}+O\left(h^{K+3}\right) .
$$

The LTE for $\operatorname{RM}(1,2)$ can be obtained by substituting $C_{3}$ given in (11) into (27) from Definition 2, which yields;

$$
\operatorname{LTE}_{R M(1,2)}=h^{3}\left(-\frac{y_{n+2}^{\prime} y_{n+2}^{\prime \prime \prime}}{3 y_{n+2}^{\prime \prime}}+\frac{y_{n+2}^{\prime \prime}}{2}\right)+O\left(h^{4}\right)
$$

Meanwhile, for $\operatorname{RM}(1,3), C_{4}$ given in (18) is substituted into (27), which yields;

$$
\operatorname{LTE}_{R M(1,3)}=h^{4}\left(-\frac{y_{n+2}^{\prime \prime} y_{n+2}^{(4)}}{8 y_{n+2}^{\prime \prime \prime}}+\frac{y_{n+2}^{\prime \prime \prime}}{6}\right)+O\left(h^{5}\right) .
$$

The LTE for $\mathrm{RM}(1,4)$ is determined by substituting $C_{5}$ given in (25) into (27), which yields;

$$
L T E_{R M(1,4)}=h^{5}\left(-\frac{y_{n+2}^{\prime \prime \prime} y_{n+2}^{(5)}}{30 y_{n+2}^{(4)}}+\frac{y_{n+2}^{(4)}}{24}\right)+O\left(h^{6}\right),
$$

where by localizing assumption, $y_{n+2}=y\left(x_{n+2}\right), y_{n+2}^{\prime}=y^{\prime}$ $\left(x_{n+2}\right), y_{n+2}^{\prime \prime}=y^{\prime \prime}\left(x_{n+2}\right), y^{\prime \prime \prime}{ }_{n+2}=y^{\prime \prime \prime}\left(x_{n+2}\right)$ and $y_{n+2}^{(4)}=y^{(4)}\left(x_{n+2}\right)$.

\section{STABILITY REGIONS OF RM $(1, p)$}

To obtain the region of absolute stability of $\operatorname{RM}(1, p), p=$ $2,3,4$, we apply the Dahlquist's test equation, $y^{\prime}=\lambda y$ to the formulas. Meanwhile, the A-stability of the methods is analyzed according to the definition mentioned in Lambert (1973).

Definition 3. A numerical method is said to be A-stable if its region of absolute stability contains the whole left-hand half-plane $\operatorname{Re}(h \lambda)<0$.

\section{STABILITY REGION OF RM(1,2)}

Applying the test equations to $\operatorname{RM}(1,2)$ in $(12)$ yields the difference equation;

$$
y_{n+3}=y_{n+2}\left[\frac{2+h \lambda}{2-h \lambda}\right] .
$$

Next, $z=h \lambda, y_{n+3}=\xi^{3}$ and $y_{n+2}=\xi^{2}$ are substituted into (31), which yields the stability function as follows;

$$
R(z)_{R M(1,2)}=\xi=\frac{2+z}{2-z} .
$$

Taking $z=x+i y$ into (32), the region of absolute stability of $\operatorname{RM}(1,2)$ is illustrated in Figure 1, with the condition $\left|R(z)_{R M(1,2)}\right| \leq 1$ is satisfied.

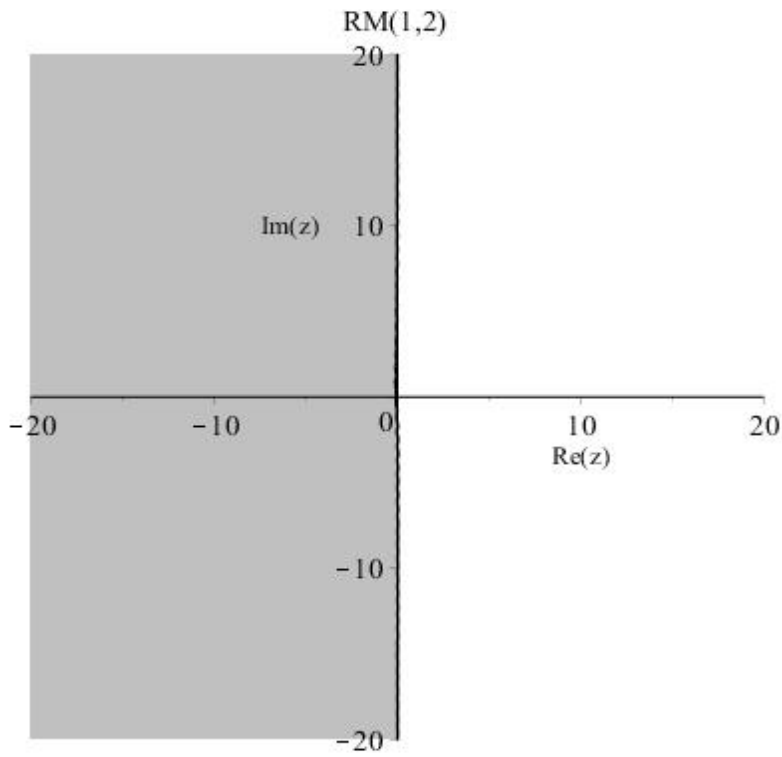

FIGURE 1 . Region of absolute stability of $\operatorname{RM}(1,2)$ 
Since the region of absolute stability of $\operatorname{RM}(1,2)$ contains the whole left-hand half-plane, thus it can be concluded that the method is A-stable.

\section{STABILITY REGION OF RM(1,3)}

To obtain the region of absolute stability of $\mathrm{RM}(1,3)$, we apply the test equation into (19) which yields;

$$
y_{n+3}=y_{n+2}\left[\frac{6+4 h \lambda+h^{2} \lambda^{2}}{6-2 h \lambda}\right]
$$

Next, $z=h \lambda, y_{n+3}=\xi^{3}$ and $y_{n+2}=\xi^{2}$ are substituted into (33), which yields the stability function as follows;

$$
R(z)_{R M(1,3)}=\xi=\frac{6+4 z+z^{2}}{6-2 z} .
$$

Substituting $z=x+i y$ into (34), the region of absolute stability of $\operatorname{RM}(1,3)$ is illustrated as in Figure 2, with the condition $\left|R(z)_{R M(1,3)}\right| \leq 1$ is satisfied.

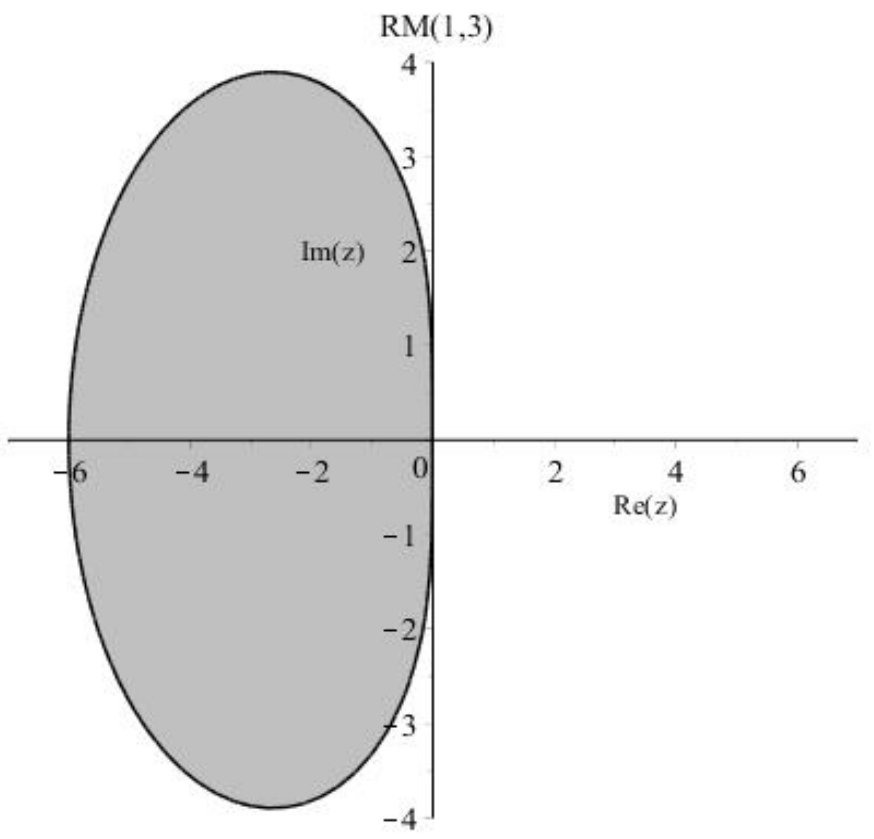

FIGURE 2. Region of absolute stability of $\operatorname{RM}(1,3)$

Based on Figure 2, it can be observed that the region of absolute stability of $\mathrm{RM}(1,3)$ is bounded and does not satisfy Definition 3. Thus, it can be concluded that the method is not A-stable.

\section{STABILITY REGION OF RM(1,4)}

As the test equation is applied to $\operatorname{RM}(1,4)$ in $(26)$, we have the following difference equation;

$$
y_{n+3}=y_{n+2}\left[\frac{24+18 h \lambda+6 h^{2} \lambda^{2}+h^{3} \lambda^{3}}{24-6 h \lambda}\right] .
$$

By substituting $z=h \lambda, y_{n+3}=\xi^{3}$ and $y_{n+2}=\xi^{2}$ into (35), the stability function is obtained as follows;

$$
R(z)_{R M(1,4)}=\xi=\frac{24+18 z+6 z^{2}+z^{3}}{24-6 z} .
$$

Next, $z=x+i y$ by substituting into (36), the region of absolute stability of $\operatorname{RM}(1,4)$ is obtained as in Figure 3, with the condition $\left|R(z)_{R M(1,4)}\right| \leq 1$ is satisfied. 


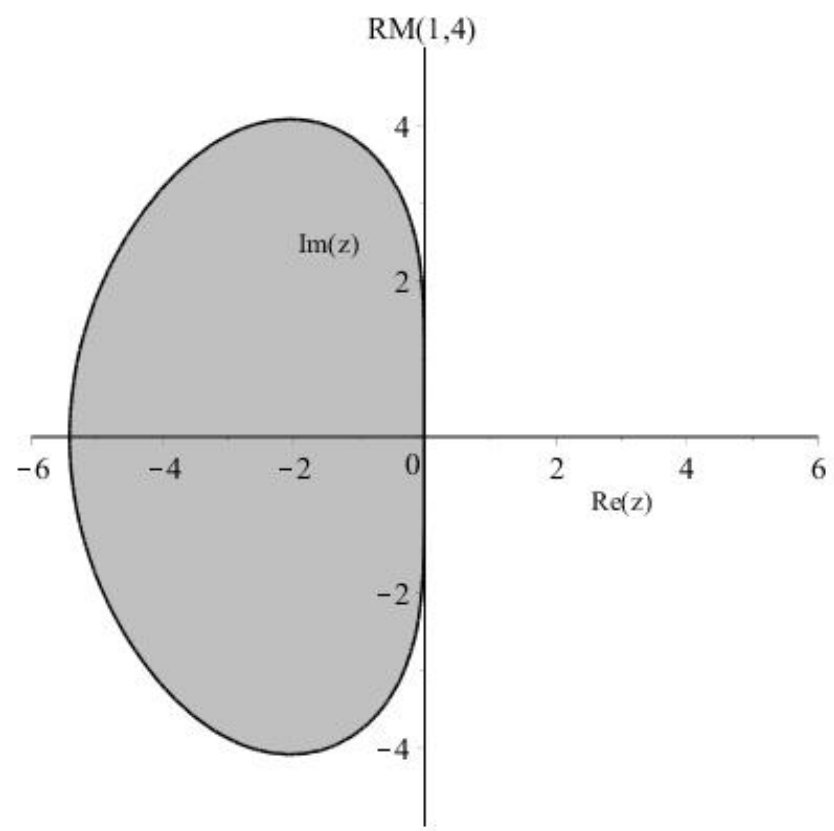

FIGURE 3. Region of absolute stability of $\operatorname{RM}(1,4)$

Figure 3 shows that the region of absolute stability of $\operatorname{RM}(1,4)$ is bounded and not A-stable. Besides that, it is noticed that the region is slightly smaller compared to the region of absolute stability of $\operatorname{RM}(1,3)$.

\section{IMPLEMENTATION}

In order to implement the developed methods, it is necessary to apply a suitable approach to calculate the starting values. In this article, we apply the rational method of order four proposed by Lambert (1973) to compute these values. The formula of the method is given by;

$$
y_{n+1}=y_{n}+h y_{n}^{\prime}+\frac{h^{2}}{2} y_{n}^{\prime \prime}+\frac{h^{3}}{6} y_{n}^{\prime \prime \prime}+\frac{h^{4}}{6}\left[\frac{y_{n}^{\prime \prime \prime} y_{n}^{(4)}}{4 y_{n}^{\prime \prime \prime}-h y_{n}^{(4)}}\right]
$$

Besides that, to determine the higher derivatives of the problem required by the proposed schemes, the following formula is applied:

$$
\left.y^{k+1}(x)\right|_{x=x_{n}}=\left.\frac{d^{k} f(x, y(x))}{d x^{k}}\right|_{x=x_{n}} \approx y_{n}^{(k+1)} .
$$

In this article, the numerical results given by $\mathrm{RM}(1$, $p), p=2,3,4$ are compared to several existing methods that have been tested on problems with singularity, stiff problems and singularly perturbed problems. For this purpose, we calculate the absolute error of the approximation given by;

$$
\text { error }_{i}=\left|y_{i}-y\left(x_{i}\right)\right|,
$$

where $y_{i}$ and $y\left(x_{i}\right)$ are the approximate and the exact solutions at point $x_{i}$, respectively; and its maximum and average error are given as;

$$
\begin{aligned}
& \text { MAX }=\max _{0 \leq i \leq T}\left(\text { error }_{i}\right), \\
& \mathrm{AVE}=\frac{1}{T} \sum_{i=1}^{T} \text { error }_{i},
\end{aligned}
$$

respectively, where $T$ is the total step.

\section{RESULTS AND DISCUSSION}

The proposed methods are examined on several problems of different type, which are problems that solution possesses singularity, stiff problems, and singularly perturbed problems.

(i) Problem 1 (Problem which solution possesses singularity)

$y^{\prime}(x)=1+(y(x))^{2}, y(0)=1,0 \leq x \leq 0.8$

Exact solution: $y(x)=\tan \left(x+\frac{\pi}{4}\right)$.

Singular point: $x=\frac{\pi}{4}$.

Source: Teh and Yaacob (2013) 
(ii) Problem 2 (Problem which solution possesses singularity)

$y^{\prime}(x)=-4+4 y(x)-(y(x))^{2}, y(0)=1,0 \leq x \leq 2$

Exact solution: $y(x)=\frac{2 x-1}{x-1}$.

Singular point: $x=1$

Source: Ramos (2007)

(iii) Problem 3 (Stiff problem)

$y^{\prime}(x)=-100 y(x)+99 e^{2 x}, y(0)=0,0 \leq x \leq 0.5$

Exact solution: $y(x)=\frac{33}{34}\left(e^{2 x}-e^{-100 x}\right)$.

Source: Teh and Yaacob (2013)

(iv) Problem 4 (Stiff problem)

$y^{\prime}(x)=-10 x y(x), y(0)=1,0 \leq x \leq 10$

Exact solution: $y(x)=e^{-5 x^{2}}$

Source: Musa et al. (2012)

(v) Problem 5 (Singularly perturbed problem)

$y^{\prime}(x)=-2 k(y(x))^{2}, y(0)=10, k=500,0 \leq x \leq 1$

Exact solution: $y(x)=\frac{10}{1+20 k x}$

Source: Ramos (2007)

The following tables show the numerical results given by the proposed methods compared to several existing methods of rational and Backward Differentiation Formula (BDF) type. The method RMM3(2, $p), p=2,3,4$ of second, third and fourth order introduced by Teh and Yaacob (2013) is re-executed on Problem 1-5 for comparison purposes in this study

The notations used in the tables are:

$\begin{array}{ll}\mathrm{N} & : \text { Number of subinterval } \\ \text { AVE } & : \text { Average error }\end{array}$

\begin{tabular}{|c|c|c|}
\hline MAX & & Maximum error \\
\hline Time & & Time of execution in second \\
\hline NS & : & $\begin{array}{l}\text { Second Order Non-standard method in } \\
\text { Ramos (2007) }\end{array}$ \\
\hline 3BEBDF & $:$ & $\begin{array}{l}\text { 3-Point Fifth Order Block Extended BDF in } \\
\text { Musa et al. (2012) }\end{array}$ \\
\hline 2IBBDF & : & $\begin{array}{l}\text { 2-Point Third Order Improved Block BDF } \\
\text { in Musa et al. (2013) }\end{array}$ \\
\hline $\operatorname{RM}(1,2)$ & : & $\begin{array}{l}\text { Second Order Rational Method proposed } \\
\text { in (12) }\end{array}$ \\
\hline $\operatorname{RM}(1,3)$ & : & $\begin{array}{l}\text { Third Order Rational Method proposed in } \\
\text { (19) }\end{array}$ \\
\hline $\operatorname{RM}(1,4)$ & : & $\begin{array}{l}\text { Fourth Order Rational Method proposed } \\
\text { in (26) }\end{array}$ \\
\hline $\operatorname{RMM} 3(2,2)$ & : & $\begin{array}{l}\text { 2-step Second Order Rational Multistep } \\
\text { Method in Teh and Yaacob (2013) }\end{array}$ \\
\hline $\operatorname{RMM} 3(2,3)$ & : & $\begin{array}{l}\text { 2-step Third Order Rational Multistep } \\
\text { Method in Teh and Yaacob (2013) }\end{array}$ \\
\hline $\operatorname{RMM} 3(2,4)$ & . & $\begin{array}{l}\text { 2-step Fourth Order Rational Multistep } \\
\text { Method in Teh and Yaacob (2013) }\end{array}$ \\
\hline & & No data has been reported for this reference \\
\hline
\end{tabular}

TABLE 1. Numerical results of RM(1,p), RMM3(2,p) and NS for solving Problem 1

\begin{tabular}{|c|c|c|c|c|}
\hline $\mathrm{N}$ & Methods & MAX & AVE & Time \\
\hline \multirow[t]{7}{*}{64} & NS & $9.47 \mathrm{e}+00$ & - & - \\
\hline & $\operatorname{RMM} 3(2,2)$ & $3.96 \mathrm{e}+01$ & $9.82 \mathrm{e}-01$ & $2.03 \mathrm{e}-01$ \\
\hline & $\mathrm{RM}(1,2)$ & $9.47 \mathrm{e}+00$ & $1.59 \mathrm{e}-01$ & $9.00 \mathrm{e}-02$ \\
\hline & $\operatorname{RMM} 3(2,3)$ & $1.55 \mathrm{e}-03$ & $2.61 \mathrm{e}-05$ & $3.76 \mathrm{e}-01$ \\
\hline & $\mathrm{RM}(1,3)$ & $1.73 \mathrm{e}-02$ & $2.92 \mathrm{e}-04$ & $3.23 \mathrm{e}-01$ \\
\hline & $\operatorname{RMM} 3(2,4)$ & $1.55 \mathrm{e}-03$ & $2.61 \mathrm{e}-05$ & $1.50 \mathrm{e}-01$ \\
\hline & $\mathrm{RM}(1,4)$ & $1.58 \mathrm{e}-04$ & $2.67 \mathrm{e}-06$ & $1.31 \mathrm{e}-01$ \\
\hline \multirow[t]{7}{*}{128} & NS & $2.33 \mathrm{e}+00$ & - & - \\
\hline & $\operatorname{RMM} 3(2,2)$ & $9.47 \mathrm{e}+00$ & $1.05 \mathrm{e}-01$ & $5.13 \mathrm{e}-01$ \\
\hline & $\operatorname{RM}(1,2)$ & $2.33 \mathrm{e}+00$ & $2.59 \mathrm{e}-02$ & $1.14 \mathrm{e}-01$ \\
\hline & $\operatorname{RMM} 3(2,3)$ & $1.20 \mathrm{e}-04$ & $1.34 \mathrm{e}-06$ & $1.19 \mathrm{e}-01$ \\
\hline & $\mathrm{RM}(1,3)$ & $2.12 \mathrm{e}-03$ & $2.37 \mathrm{e}-05$ & $1.17 \mathrm{e}-01$ \\
\hline & $\operatorname{RMM} 3(2,4)$ & $1.20 \mathrm{e}-04$ & $1.34 \mathrm{e}-06$ & $8.10 \mathrm{e}-01$ \\
\hline & $\operatorname{RM}(1,4)$ & $3.16 \mathrm{e}-05$ & $3.54 \mathrm{e}-07$ & $4.50 \mathrm{e}-01$ \\
\hline \multirow[t]{7}{*}{256} & NS & $2.43 \mathrm{e}+00$ & - & - \\
\hline & $\operatorname{RMM} 3(2,2)$ & $9.62 \mathrm{e}+00$ & $5.36 \mathrm{e}-02$ & $1.34 \mathrm{e}+00$ \\
\hline & $\mathrm{RM}(1,2)$ & $2.43 e+00$ & $1.35 \mathrm{e}-02$ & $1.24 \mathrm{e}+00$ \\
\hline & $\operatorname{RMM} 3(2,3)$ & $1.23 \mathrm{e}-04$ & $6.84 \mathrm{e}-07$ & $2.33 \mathrm{e}-01$ \\
\hline & $\operatorname{RM}(1,3)$ & $1.03 \mathrm{e}-03$ & $5.71 \mathrm{e}-06$ & $1.78 \mathrm{e}-01$ \\
\hline & $\operatorname{RMM} 3(2,4)$ & $1.23 \mathrm{e}-04$ & $6.84 \mathrm{e}-07$ & $2.50 \mathrm{e}-01$ \\
\hline & $\mathrm{RM}(1,4)$ & $1.00 \mathrm{e}-04$ & $5.56 \mathrm{e}-07$ & $2.43 \mathrm{e}-01$ \\
\hline
\end{tabular}


TABLE 2. Numerical results of RM(1,p), RMM3(2,p) and NS for solving Problem 2

\begin{tabular}{|c|c|c|c|c|}
\hline $\mathrm{N}$ & Methods & MAX & AVE & Time \\
\hline \multirow[t]{7}{*}{32} & NS & $5.18 \mathrm{e}-13$ & - & - \\
\hline & $\operatorname{RMM} 3(2,2)$ & $3.31 \mathrm{e}+01$ & $3.76 \mathrm{e}+00$ & $9.90 \mathrm{e}-02$ \\
\hline & $\operatorname{RM}(1,2)$ & $4.26 \mathrm{e}-13$ & $2.99 \mathrm{e}-14$ & $7.80 \mathrm{e}-02$ \\
\hline & $\operatorname{RMM} 3(2,3)$ & $3.11 \mathrm{e}+01$ & $3.62 \mathrm{e}+00$ & $1.93 \mathrm{e}-02$ \\
\hline & $\operatorname{RM}(1,3)$ & $4.05 \mathrm{e}-13$ & $2.99 \mathrm{e}-14$ & $1.60 \mathrm{e}-02$ \\
\hline & $\operatorname{RMM} 3(2,4)$ & $3.11 \mathrm{e}+01$ & $3.62 \mathrm{e}+00$ & $1.09 \mathrm{e}-02$ \\
\hline & $\operatorname{RM}(1,4)$ & $3.53 \mathrm{e}-13$ & $2.52 \mathrm{e}-14$ & $1.03 \mathrm{e}-02$ \\
\hline \multirow[t]{7}{*}{64} & NS & $2.70 \mathrm{e}-13$ & - & - \\
\hline & $\operatorname{RMM} 3(2,2)$ & $6.31 \mathrm{e}+01$ & $4.31 \mathrm{e}+00$ & $6.25 \mathrm{e}-01$ \\
\hline & $\mathrm{RM}(1,2)$ & $3.77 \mathrm{e}-13$ & $1.41 \mathrm{e}-14$ & $9.40 \mathrm{e}-02$ \\
\hline & $\operatorname{RMM} 3(2,3)$ & $6.31 \mathrm{e}+01$ & $4.26 \mathrm{e}+00$ & $2.03 \mathrm{e}-01$ \\
\hline & $\operatorname{RM}(1,3)$ & $2.42 \mathrm{e}-13$ & $1.41 \mathrm{e}-14$ & $1.30 \mathrm{e}-01$ \\
\hline & $\operatorname{RMM} 3(2,4)$ & $6.31 \mathrm{e}+01$ & $4.26 \mathrm{e}+00$ & $4.22 \mathrm{e}-01$ \\
\hline & $\mathrm{RM}(1,4)$ & $2.70 \mathrm{e}-13$ & $1.42 \mathrm{e}-14$ & $1.57 \mathrm{e}-01$ \\
\hline \multirow[t]{7}{*}{128} & NS & $1.99 \mathrm{e}-11$ & - & - \\
\hline & $\operatorname{RMM} 3(2,2)$ & $1.27 \mathrm{e}+02$ & $4.77 \mathrm{e}+00$ & $1.82 \mathrm{e}+00$ \\
\hline & $\mathrm{RM}(1,2)$ & $2.08 \mathrm{e}-11$ & $3.95 \mathrm{e}-13$ & $1.72 \mathrm{e}-01$ \\
\hline & $\operatorname{RMM} 3(2,3)$ & $1.27 \mathrm{e}+02$ & $4.92 \mathrm{e}+00$ & $1.87 \mathrm{e}-01$ \\
\hline & $\mathrm{RM}(1,3)$ & $2.07 \mathrm{e}-11$ & $3.93 \mathrm{e}-13$ & $1.41 \mathrm{e}-01$ \\
\hline & $\operatorname{RMM} 3(2,4)$ & $1.27 \mathrm{e}+02$ & $4.92 \mathrm{e}+00$ & $5.73 \mathrm{e}-01$ \\
\hline & $\mathrm{RM}(1,4)$ & $2.07 \mathrm{e}-11$ & $3.94 \mathrm{e}-13$ & $5.30 \mathrm{e}-01$ \\
\hline
\end{tabular}

TABLE 3. Numerical results of RM(1,p), RMM3(2,p) and NS for solving Problem 3

\begin{tabular}{|c|c|c|c|c|}
\hline $\mathrm{N}$ & Methods & MAX & AVE & Time \\
\hline \multirow[t]{7}{*}{64} & NS & $1.78 \mathrm{e}-02$ & - & - \\
\hline & $\operatorname{RMM} 3(2,2)$ & $7.82 \mathrm{e}-02$ & $2.42 \mathrm{e}-03$ & $3.07 \mathrm{e}-02$ \\
\hline & $\mathrm{RM}(1,2)$ & $2.94 \mathrm{e}-03$ & $1.27 \mathrm{e}-04$ & $1.57 \mathrm{e}-02$ \\
\hline & $\operatorname{RMM} 3(2,3)$ & $5.85 e-03$ & $3.52 \mathrm{e}-04$ & $1.50 \mathrm{e}-02$ \\
\hline & $\operatorname{RM}(1,3)$ & $5.03 \mathrm{e}-04$ & $7.72 \mathrm{e}-05$ & $1.40 \mathrm{e}-02$ \\
\hline & $\operatorname{RMM} 3(2,4)$ & $6.58 \mathrm{e}-02$ & $2.38 \mathrm{e}-02$ & $2.03 e-02$ \\
\hline & $\mathrm{RM}(1,4)$ & $3.83 \mathrm{e}-04$ & $5.27 \mathrm{e}-05$ & $1.60 \mathrm{e}-02$ \\
\hline \multirow[t]{7}{*}{128} & NS & $4.14 \mathrm{e}-03$ & - & - \\
\hline & $\operatorname{RMM} 3(2,2)$ & $1.78 \mathrm{e}-02$ & $6.51 \mathrm{e}-04$ & $5.20 \mathrm{e}-02$ \\
\hline & $\mathrm{RM}(1,2)$ & $1.72 \mathrm{e}-03$ & $7.40 \mathrm{e}-05$ & $4.60 \mathrm{e}-02$ \\
\hline & $\operatorname{RMM} 3(2,3)$ & $6.14 \mathrm{e}-04$ & $4.21 \mathrm{e}-05$ & $4.60 \mathrm{e}-02$ \\
\hline & $\operatorname{RM}(1,3)$ & $1.45 \mathrm{e}-04$ & $1.61 \mathrm{e}-05$ & $4.50 \mathrm{e}-02$ \\
\hline & $\operatorname{RMM} 3(2,4)$ & $7.28 \mathrm{e}-03$ & $3.37 \mathrm{e}-04$ & $5.13 e-02$ \\
\hline & $\mathrm{RM}(1,4)$ & $2.02 \mathrm{e}-05$ & $8.56 \mathrm{e}-06$ & $4.70 \mathrm{e}-02$ \\
\hline \multirow[t]{7}{*}{256} & NS & $1.03 \mathrm{e}-03$ & - & - \\
\hline & $\operatorname{RMM} 3(2,2)$ & $4.15 \mathrm{e}-03$ & $1.75 \mathrm{e}-04$ & $9.33 e-02$ \\
\hline & $\operatorname{RM}(1,2)$ & $6.65 \mathrm{e}-04$ & $2.97 \mathrm{e}-05$ & $9.15 \mathrm{e}-02$ \\
\hline & $\operatorname{RMM} 3(2,3)$ & $7.41 \mathrm{e}-05$ & $5.20 \mathrm{e}-06$ & $2.03 e-01$ \\
\hline & $\operatorname{RM}(1,3)$ & $2.62 \mathrm{e}-05$ & $3.29 \mathrm{e}-06$ & $1.90 \mathrm{e}-01$ \\
\hline & $\operatorname{RMM} 3(2,4)$ & $1.29 \mathrm{e}-05$ & $4.48 \mathrm{e}-05$ & $1.09 \mathrm{e}-01$ \\
\hline & $\mathrm{RM}(1,4)$ & $4.38 \mathrm{e}-06$ & $1.85 \mathrm{e}-06$ & $9.30 \mathrm{e}-02$ \\
\hline
\end{tabular}


TABLE 4. Numerical results of RM(1,p), RMM3(2,p), 3BEBDF and 2IBBDF for solving Problem 4

\begin{tabular}{|c|c|c|c|c|}
\hline $\mathrm{N}$ & Methods & MAX & AVE & Time \\
\hline \multirow[t]{8}{*}{500} & 3BEBDF & - & - & - \\
\hline & 2IBBDF & - & - & - \\
\hline & RMM3(2,2) & $1.98 \mathrm{e}+00$ & $3.59 \mathrm{e}-02$ & $1.37 \mathrm{e}+00$ \\
\hline & $\operatorname{RM}(1,2)$ & $1.79 \mathrm{e}-03$ & $8.91 \mathrm{e}-05$ & $2.04 \mathrm{e}-01$ \\
\hline & $\operatorname{RMM} 3(2,3)$ & $1.06 \mathrm{e}-02$ & $3.83 \mathrm{e}-04$ & $1.07 \mathrm{e}+00$ \\
\hline & $\operatorname{RM}(1,3)$ & $2.47 \mathrm{e}-04$ & $1.37 \mathrm{e}-05$ & $1.84 \mathrm{e}-01$ \\
\hline & RMM3 $(2,4)$ & $1.97 \mathrm{e}+00$ & $3.59 \mathrm{e}-02$ & $2.00 \mathrm{e}+00$ \\
\hline & $\mathrm{RM}(1,4)$ & $2.18 \mathrm{e}-04$ & $1.23 \mathrm{e}-05$ & $4.97 \mathrm{e}-01$ \\
\hline \multirow[t]{8}{*}{1000} & 3BEBDF & $1.24 \mathrm{e}-02$ & - & - \\
\hline & 2IBBDF & $1.49 \mathrm{e}-03$ & - & - \\
\hline & RMM3(2,2) & $2.00 \mathrm{e}+00$ & $3.77 \mathrm{e}-02$ & $1.91 \mathrm{e}+00$ \\
\hline & $\mathrm{RM}(1,2)$ & $5.98 \mathrm{e}-04$ & $2.94 \mathrm{e}-05$ & $1.66 \mathrm{e}+00$ \\
\hline & RMM3(2,3) & $2.80 \mathrm{e}-03$ & $1.02 \mathrm{e}-04$ & $1.84 \mathrm{e}+00$ \\
\hline & $\operatorname{RM}(1,3)$ & $6.17 \mathrm{e}-05$ & $3.86 \mathrm{e}-06$ & $1.83 \mathrm{e}+00$ \\
\hline & RMM3 $(2,4)$ & $1.97 \mathrm{e}+00$ & $3.59 \mathrm{e}-02$ & $2.12 \mathrm{e}+00$ \\
\hline & $\mathrm{RM}(1,4)$ & $5.30 \mathrm{e}-05$ & $3.03 \mathrm{e}-06$ & $4.97 \mathrm{e}-01$ \\
\hline \multirow[t]{8}{*}{10000} & 3BEBDF & $7.36 \mathrm{e}-04$ & - & - \\
\hline & 2IBBDF & $1.51 \mathrm{e}-05$ & - & - \\
\hline & RMM3(2,2) & $2.00 \mathrm{e}+00$ & $3.94 \mathrm{e}-02$ & $1.03 \mathrm{e}+01$ \\
\hline & $\operatorname{RM}(1,2)$ & $1.11 \mathrm{e}-05$ & $5.27 \mathrm{e}-07$ & $5.47 \mathrm{e}+00$ \\
\hline & RMM3(2,3) & $2.99 \mathrm{e}-05$ & $1.10 \mathrm{e}-06$ & $1.88 \mathrm{e}+01$ \\
\hline & $\mathrm{RM}(1,3)$ & $5.18 \mathrm{e}-07$ & $3.00 \mathrm{e}-08$ & $7.00 \mathrm{e}+00$ \\
\hline & RMM3 $(2,4)$ & $2.00 \mathrm{e}+00$ & $3.92 \mathrm{e}-02$ & $1.46 \mathrm{e}+01$ \\
\hline & $\mathrm{RM}(1,4)$ & $5.16 \mathrm{e}-07$ & $2.99 \mathrm{e}-08$ & $9.86 \mathrm{e}+00$ \\
\hline
\end{tabular}

TABLE 5. Numerical results of RM(1,p), RMM3(2,p) and NS for solving Problem 5

\begin{tabular}{|c|c|c|c|c|}
\hline $\mathrm{N}$ & Methods & MAX & AVE & Time \\
\hline \multirow[t]{7}{*}{32} & NS & $8.67 e-16$ & - & - \\
\hline & $\operatorname{RMM} 3(2,2)$ & Fail at $x=0.03125$ & - & $1.50 \mathrm{e}-02$ \\
\hline & $\mathrm{RM}(1,2)$ & $1.01 \mathrm{e}-11$ & $5.11 \mathrm{e}-13$ & $1.47 \mathrm{e}-02$ \\
\hline & $\operatorname{RMM} 3(2,3)$ & Fail at $x=0.03125$ & - & $1.50 \mathrm{e}-02$ \\
\hline & $\mathrm{RM}(1,3)$ & $1.01 \mathrm{e}-11$ & $5.11 \mathrm{e}-13$ & $1.30 \mathrm{e}-02$ \\
\hline & $\operatorname{RMM} 3(2,4)$ & Fail at $x=0.03125$ & - & $1.50 \mathrm{e}-02$ \\
\hline & $\mathrm{RM}(1,4)$ & $1.01 \mathrm{e}-11$ & $5.11 \mathrm{e}-13$ & $1.43 \mathrm{e}-02$ \\
\hline \multirow[t]{7}{*}{64} & NS & $7.63 e-16$ & - & - \\
\hline & $\operatorname{RMM} 3(2,2)$ & Fail at $x=0.015625$ & - & $2.50 \mathrm{e}-02$ \\
\hline & $\mathrm{RM}(1,2)$ & $2.50 \mathrm{e}-12$ & $6.38 \mathrm{e}-14$ & $2.10 \mathrm{e}-02$ \\
\hline & $\operatorname{RMM} 3(2,3)$ & Fail at $x=0.015625$ & - & $2.75 \mathrm{e}-02$ \\
\hline & $\mathrm{RM}(1,3)$ & $2.50 \mathrm{e}-12$ & $6.38 \mathrm{e}-14$ & $2.50 \mathrm{e}-02$ \\
\hline & $\operatorname{RMM} 3(2,4)$ & Fail at $x=0.015625$ & - & $3.10 \mathrm{e}-02$ \\
\hline & $\operatorname{RM}(1,4)$ & $2.50 \mathrm{e}-12$ & $6.38 \mathrm{e}-14$ & $3.10 \mathrm{e}-02$ \\
\hline \multirow[t]{7}{*}{128} & NS & $7.21 \mathrm{e}-16$ & - & - \\
\hline & $\operatorname{RMM} 3(2,2)$ & Fail at $x=0.007813$ & - & $5.12 \mathrm{e}-02$ \\
\hline & $\mathrm{RM}(1,2)$ & $2.60 \mathrm{e}-13$ & $3.35 \mathrm{e}-15$ & $4.30 \mathrm{e}-02$ \\
\hline & $\operatorname{RMM} 3(2,3)$ & Fail at $x=0.007813$ & - & $5.13 \mathrm{e}-02$ \\
\hline & $\mathrm{RM}(1,3)$ & $2.60 \mathrm{e}-13$ & $3.35 \mathrm{e}-15$ & $4.80 \mathrm{e}-02$ \\
\hline & $\operatorname{RMM} 3(2,4)$ & Fail at $x=0.007813$ & - & $8.30 \mathrm{e}-02$ \\
\hline & $\operatorname{RM}(1,4)$ & $2.60 \mathrm{e}-13$ & $3.35 e-15$ & $6.40 \mathrm{e}-02$ \\
\hline
\end{tabular}


Tables 1 to 2 show the numerical results of $\operatorname{RM}(1, p)$, $p=2,3,4$ for solving problems with singularity. From Table 1 , it is shown that $\operatorname{RM}(1, p)$ gives more accurate or comparable approximations to NS and RMM3(2,p), as methods of the same order are compared. This is in contrast with the third order method, $\operatorname{RM}(1,3)$, since the given errors are slightly larger than RMM3 $(2,3)$. Meanwhile, in solving Problem 2, different values of constant step size are used to cross the singular point, $x=$ 1 , which is an integer where the results are tabulated as in Table 2. From the results, it is clear that the approximation given by $\operatorname{RM}(1, p)$ is more accurate or comparable to NS and $\operatorname{RMM} 3(2, p)$ of the same order. Moreover, it also appears that $\operatorname{RM}(1,2), \operatorname{RM}(1,3)$ and $\operatorname{RM}(1,4)$ are comparably accurate in generating the numerical solutions of problems.

Meanwhile, Tables 3 to 4 display the results generated by the proposed methods for solving stiff problems (Problems 3 and 4). From these tables, it is noticed that $\operatorname{RM}(1, p)$ are capable in giving smaller maximum and average errors compared to NS and $\operatorname{RMM} 3(2, p)$ of the same order. Besides that, the proposed methods are also compared to some BDF type methods, which are known for its capability in solving stiff problems in Table 4. It is shown that the results given by $\operatorname{RM}(1, p)$ are more accurate compared to 3BEBDF and 2IBBDF, which are fifth and third order methods. Apart from that, it is also shown that $\operatorname{RM}(1, p)$ is capable in generating better approximation as the order and the values of increases in solving these problems.

The capability of the $\operatorname{RM}(1, p)$ in solving Problem 5 is presented in Table 5, as it can be observed that the proposed methods are capable in generating small values of maximum and average errors in comparison to $\operatorname{RMM} 3(2, p)$, which fails to approximate the problem at certain point of the desired interval. However, as the second order methods are compared, NS generates more accurate solutions compared to $\operatorname{RM}(1, p)$ due to its selfstarting nature. It is also noticed that, for the same value of $N$, the results given by $\mathrm{RM}(1,2), \operatorname{RM}(1,3)$ and $\mathrm{RM}(1,4)$ are comparably accurate.

Additionally, the results for the execution time of $\operatorname{RM}(1, p)$ in Tables 1 to 5 show that the time taken by $\mathrm{RM}(1, p)$ is comparable or lesser compared to $\operatorname{RMM} 3(2, p)$. Hence, this indicate the efficiency of $\operatorname{RM}(1, p)$ in solving the tested problems.

\section{CONCLUSION}

A class of rational methods of second to fourth-order of accuracy formulated by adapting the idea of the closest points of approximation is presented in this paper. These methods are formulated based on a rational function with the denominator of degree one proposed in the study. The illustrated region of absolute stability suggested that the second-order method is A-stable, whereas the third and fourth-order methods are not. The proposed methods are tested on problems with singularity, stiff problems and singularly perturbed problem, and the numerical results suggested that the methods are suitable in solving the considered problems. The adaptation of the idea of the closest points of approximation has given an advantage to the proposed methods to generate more accurate solutions for the tested problems than the existing rational multistep methods in most comparisons. Contrarily, as the methods are compared to a self-starting method, comparable or larger errors are exhibited by the developed methods.

\section{ACKNOWLEDGEMENTS}

The authors would like to thank Universiti Putra Malaysia for providing financial support for this research through the Putra Grant (GP-IPS/2018/9625300).

\section{REFERENCES}

Abelman, S. \& Eyre, D. 1990. A numerical study of multistep methods based on continued fraction. Computers and Mathematics with Applications 20(8): 51-60.

Adeboye, K.R. \& Umar, A.E. 2013. Generalized rational approximation method via pade approximants for the solutions of IVPs with singular solution and stiff differential equations. Journal of Mathematical Sciences 2(1): 327-368.

Fatunla, S. 1986. Numerical treatment of singular initial value problems. Computers and Mathematics with Application 12B(5-6): 1109-1115.

Gadella, M. \& Lara, L.P. 2013. A numerical method for solving ODE by rational approximation. Applied Mathematical Sciences 7(23): 1119-1130.

Ikhile, M. 2001. Coefficients for studying one-step rational schemes for ivps in odes: I. Computers and Mathematics with Applications 44(3-4): 769-781.

Lambert, J.D. 1973. Computational Methods in Ordinary Differential Equations. London: John Wiley and Sons.

Musa, H., Suleiman, M.B., Ismail, F., Senu, N. \& Ibrahim, Z.B. 2013. An improved 2-point block backward differentiation formula for solving stiff initial value problems. In AIP Conference Proceedings 1522. pp. 211-220.

Musa, H., Suleiman, M. \& Senu, N. 2012. Fully implicit 3-point block extended backward differentiation formula for stiff initial value problems. Applied Mathematical Sciences 6(85): 4211-4228.

Okosun, K.O. \& Ademiluyi, R. 2007a. A three step rational methods for integration of differential equations with singularities. Research Journal of Applied Science 2(1): 84-88.

Okosun, K.O. \& Ademiluyi, R. 2007b. A two-step second order inverse polynomial methods for integration of differential equations with singularities. Research Journal of Applied Sciences 2(1): 13-16.

Otunta, F.O. \& Nwachukwu, G.C. 2005. Rational one-step numerical integrator for initial value problems in ordinary 
differential equations. Journal of the Nigerian Association of Mathematical Physics 9: 285-295.

Ramos, H. 2007. A non-standard explicit integration scheme for initial value problem. Applied Mathematics and Computation 189: 710-718.

Ramos, H., Singh, G., Kanwar, V. \& Bhatia, S. 2017. An embedded 3(2) pair of nonlinear methods for solving first order initial-value ordinary differential system. Numerical Algorithm 75(3): 509-529.

Ramos, H., Singh, G., Kanwar, V. \& Bhatia, S. 2015. Solving first order initial value problems by using an explicit non-standard a-stable one-step method in variable step-size formulation. Applied Mathematics and Computation 268: 796-805.

Teh, Y.Y. 2014. An explicit two-step rational method for the numerical solution of first order initial value problem. In AIP Conference Proceedings 1605. pp. 96-100.

Teh, Y.Y. \& Yaacob, N. 2013. A new class of rational multistep methods for solving initial value problems. Malaysian Journal of Mathematical Science 7(1): 31-57.

Teh, Y.Y., Zurni, O. \& Mansor, K.H. 2016. Rational block method for the numerical solution of first order initial value problem I: concept and ideas. Global Journal of Pure and Applied Mathematics 12(4): 3787-3808.
Teh, Y.Y., Yaacob, N. \& Alias, N. 2011. A new class of rational multistep methods for the numerical solution of first order initial value problem. Matematika 27(1): 59-78.

A'in Nazifa Fairuz \& Zanariah Abdul Majid*

Institute for Mathematical Research

Universiti Putra Malaysia

43400 UPM Serdang, Selangor Darul Ehsan

Malaysia

Zanariah Abdul Majid* \& Zarina Bibi Ibrahim

Department of Mathematics

Faculty of Science

Universiti Putra Malaysia

43400 UPM Serdang, Selangor Darul Ehsan

Malaysia

*Corresponding author; email: am_zana@upm.edu.my

Received: 17 January 2020

Accepted: 20 May 2020 